\title{
Microscopic, Physicochemical and Phytochemical Evaluation of Stem bark of Aubrevillea kerstingii (Harms) Pellegr. (Mimosaceae)
}

\author{
${ }^{1}$ A. H. Ahmed, ${ }^{2}$ K. Y. Musa, ${ }^{2}$ A. Ahmed, and ${ }^{2}$ A.F. Mahmud \\ ${ }^{1}$ Department of Pharmacognosy and Ethnopharmacy, \\ Faculty of Pharmaceutical Sciences, \\ Usmanu Danfodiyo University, \\ Sokoto- Nigeria. \\ ${ }^{2}$ Department of Pharmacognosy and Drug Development, \\ Faculty of Pharmaceutical sciences, \\ Ahmadu Bello University, \\ Zaria-Kaduna-Nigeria
}

Email: aliyu.hamidu@udusok.edu.ng

\begin{abstract}
Microscopic, physicochemical and phytochemical evaluation gives detailed valuable information that is useful in determination of the identity, quality and purity of medicinal plants, crude drugs and herbal products. The research was carried out in order to determine the microscopic, physicochemical and phytochemical parameters of stem bark extract of Aubrevillea kerstingii. The macroscopic, microscopic, chemo-microscopic and physicochemical and preliminary phytochemical screening parameters were determined according to standard methods. The microscopic features revealed the presence of thin walled, radially arranged cork cells, well developed cortex, bundles of sclerenchymatous cells and numerous prismatic calcium oxalate crystals The chemo-microscopy of the powdered stem bark revealed the presence of some cell wall materials and cell inclusions. Physicochemical parameters determined in this study showed moisture content to be $8.2 \pm 0.07$, total ash value $9.23 \pm 0.56$, acid insoluble ash $1.49 \pm 0.12$, water soluble ash $5.52 \pm 0.10$, alcohol extractive value $26.50 \pm 0.61$ and water extractive value $33.4 \pm 0.36$. Preliminary phytochemical screening revealed the presence of saponins, triterpenes, flavonoids, tannins, alkaloids and carbohydrate. The parameters of stem bark of Aubrevillea kerstingii determined in this study will help in establishing the quality and purity of the plant.
\end{abstract}

Keywords: Aubrevillea kerstingii, Fabaceae, Physicochemical, Phytochemical

\section{INTRODUCTION}

In recent times there is renewed interest in drugs from natural sources due their good safety and increase in incidences of toxicity and side effects of synthetic drugs. Natural drugs are also more readily available at lower cost and have fewer side effects (Raina et al., 2014). The increasing demand of drugs from natural sources has led to an increase in adulteration (Chanda, 2014). Adulteration is the substitution of genuine drug or addition of another substance to increase the quantity either intentionally or not (Chanda, 2014). The efficacy of medicinal plants depends on the quality and quantity of chemical constituents. Incorrect identification of medicinal plants can lead to adulteration. It is necessary to lay down pharmacognostic standards of medicinal plants in order to address the problem of 
adulteration. Pharmacognostic studies ensure plant identity, quality, purity and lays down standardization parameters which will help in preventing adulterations (Chanda, 2014). Pharmacognostic evaluation gives detailed valuable information regarding the macroscopical, microscopical, physicochemical and phytochemical characteristics of the crude drugs (Kalpna and Chanda, 2012).

Aubrevillea kerstingii (Harms) Pellegr is a deciduous tree belonging to the family Mimosaceae with widely spreading branches and an umbrella-like crown; it can grow up to 37 meters tall. A. kerstingii is a large tree reaching $120 \mathrm{ft}$. in height and fourteen feet in girth. The bark is grey to reddish-brown, thin, horizontally striated with lenticels, and scaley on large trees. Slash is thin, hard and light brown outside with white fibres; the inner slash is yellowishbrown, layered with yellow and white fibres which tear. The straight, cylindrical bole can be up to $120 \mathrm{~cm}$ in diameter with thin buttresses often forming broadly triangular flanges merging gradually with the twisted widely spreading roots The tree is harvested from the wild for local use as a medicine and probably also for its wood. (Lemmens, 2006). Aubrevillea kerstingii is a large tree characteristic of forest outliers in the savannah. It is native to West Africa (Burkill, 1985). Traditionally the bark is used as an anodyne and to prevent abortion. Decoction of the leaf is administered in enema as a laxative. The roots and stem barks are used in treatment of oedema, kidney diseases and are used as diuretics, laxatives and for treatment of gout (Burkill, 1985). There are no previously published works on evaluation of microscopic, physicochemical and phytochemical parameters of stem bark of Aubrevillea kerstingii. The present study was conducted in order to establish pharmacognostic parameters of Aubrevillea kerstingii stem bark.

\section{MATERIALS AND METHODS}

\section{Plant Collection, Identification and Preparation}

The stem bark of Aubrevillea kerstingii was collected from Dajin Dala, unguwar Dala, along old Birnin Gwari Road, Gwargwaji Zaria Local Government Area of Kaduna State. It was identified at the Herbarium Unit of the Department of Botany, Ahmadu Bello University Zaria, Nigeria and was given a voucher number 0781. The fresh stem bark of Aubrevillea kerstingii was air dried under shade at room temperature, pulverized and stored in an airtight container for further use.

\section{Extraction}

The powdered stem bark of Aubrevillea kerstingii (1.5kg) was extracted with n-hexane, ethyl acetate and methanol using sequential maceration in increasing order of polarity. The extracts were concentrated on rotary evaporator. The extracts (n-hexane, ethyl acetate and Methanol) were kept in desiccators for further use (Supriatno, and Lelifajri, 2018).

\section{Macroscopic Examination}

Morphological features of the stem bark sample including; colour, texture, odour and appearance of both inner and outer surfaces of the fresh and dried stem bark were observed. All the features were examined using recommended procedure (WHO, 2011).

\section{Microscopic studies}

The fresh stem bark of Aubrevillea kerstingii was cut into transverse section (T.S) using microtone and cleared with alcohol, lactochloral and xylene solutions. The plant material was then stained with safranin and mounted in dilute glycerol and observed under the microscope as described by (Evans, 2002). 


\section{Chemo-microscopic Examination}

The chemo-microscopic examination of the powder sample to determine the cell walls and cell contents such as lignin, starch, mucilage, calcium oxalate crystals, cellulose, fatty oil and protein were carried out following the methods described in WHO guidelines on quality control methods for medicinal plant materials (WHO, 2011).

\section{Test for cellulose cell walls}

A drop or two of iodinated zinc chloride was added to the powdered stem bark sample and allowed to stand for a few minutes and observed under a microscope. The staining of the cellulose cell wall into blue to blue- violet colouration is indicative of positive reaction.

\section{Lignified cell walls}

The powdered stem bark material was moistened on a slide with a small volume of phloroglucinol and allowed to stand for two minutes (almost dry). A drop of hydrochloric acid was added and viewed under the microscope. The pink colouration is indicative of positive reaction.

\section{Test for suberin or cuticular cell walls}

Two drops of Sudan red were added to the powdered stem bark sample and allowed to stand for two minutes and observed under the microscope. The orange red colouration is indicative of positive reaction.

\section{Test for mucilage}

A drop of Ruthemium red was added to the dry powdered stem bark sample and viewed under the microscope. Mucilage showed up as transparent, spherically dilated fragments on a black background

\section{Calcium oxalates and calcium carbonate}

A small portion of the powdered sample of the plant was cleared in chloral hydrate, hydrochloric acid was added and dissolution of crystals in the powdered drug without effervescence was considered positive for calcium oxalate. While slow dissolution with effervescence was considered positive for calcium carbonate.

\section{Starch}

Two drops of N50 iodine was added to the powdered stem bark sample and viewed under the microscope. Blue coloration was observed, in the presence of starch.

\section{Tannins}

A drop of ferric chloride solution was added to the powdered stem bark sample and viewed under the microscope. A bluish black color observed indicates the presence of tannins.

\section{Aleurone grains}

Two drops of alcoholic picric acid in ethanol was added to the powdered stem bark sample and observed under the microscope.

\section{Determination of Physicochemical Constants}

Total ash, water soluble ash, acid insoluble ash, alcohol and water soluble extractive values, and moisture content was determined using the WHO guidelines on quality control methods for medicinal plant materials (WHO, 2011). 


\section{Preliminary Phytochemical Screening}

The methanol, ethyl acetate and n-hexane extracts was subjected to preliminary phytochemical screening using standard methods for detection of phytochemicals. (Evans, 2002).

\section{Test for carbohydrates}

(i). Molisch test: To small dissolve portion of the extract in a test tube, few drops of Molisch reagent was added and concentrated sulphuric acid was added down the side of the test tube to form a lower layer, a reddish coloured ring at the interphase will indicates presence of carbohydrate (Evans, 2009).

(ii). Fehling test: To small portion of the extract in a test tube, $5 \mathrm{ml}$ of an equal mixture of Fehling solution A and B was added and boiled on a water bath; brick red precipitate will indicate presence of reducing sugar (Evans, 2009).

\section{Test for cardiac glycosides}

(i). Keller-Killiani Test: $0.5 \mathrm{~g}$ of the extracts was dissolved in $2 \mathrm{ml}$ of glacial acetic acid containing one drop of ferric chloride solution. This will then be under layered with $1 \mathrm{ml}$ of concentrated sulphuric acid. A brown ring obtained at the interphase indicates the presence of deoxy-sugar characteristic of cardenolides (Evans, 2009).

(ii). Kedde's Test: Few drops of $2 \%$ solution of 3, 5-dinitrobenzole acid in 95\% alcohol were added to small portion of filtrate. A solution of $5 \%$ sodium hydroxide was added to make the solution alkaline, appearance of purple-blue colour indicate the presence of cardinolides (Evans 2009).

\section{Test for cyanogenic glycoside (Guignard Reaction Test)}

Small quantity of the fresh material was crushed and mixed with $5 \mathrm{ml}$ of water in a test tube. A prepared damp sodium picrate paper was suspended at the mouth of the test tube by means of a cork. The tube was placed in water bath for one hour. A brick red colour on the picrate paper will indicate the presence of Cyanogenic glycoside.

\section{Test for saponins}

(i). Frothing test: $0.5 \mathrm{~g}$ of the extracts was shaken with water in a test tube followed by warming on a water bath. Frothing which persists on warming was taken as an evidence for the presence of saponins (Sofowora, 1996).

(ii). Hemolysis test: $2 \mathrm{ml}$ of sodium chloride (1.8\% solution in distilled water) was added to two test tubes A and B. $2 \mathrm{ml}$ of distilled water was added to test tube A, $2 \mathrm{ml}$ of the extract was added to test tube B. 5 drops of blood was added to each tube and the tubes was inverted gently to mix the contents. Hemolysis in tube B containing the extract but not in tube A (i.e. control), would indicate the presence of saponins in the extract (Alam and Najum, 2015).

\section{Test for flavonoids}

(i). Shinoda test: About $0.5 \mathrm{~g}$ of the extracts was dissolved in $5 \mathrm{ml} 95 \%$ ethanol, warmed and filtered. Three (3) pieces of magnesium chips was added followed by five drops of concentrated hydrochloric acid. The appearance of a pink, orange or red to purple color indicates the presence of flavonoids (Evans, 2009).

(ii). Sodium hydroxide test: Few quantities of the extracts was dissolved in water and filtered; $2 \mathrm{ml}$ of $10 \%$ aqueous sodium hydroxide solution will then be added. The solution was observed for the presence of yellow color, a change in color from yellow to colorless on addition of dilute hydrochloric acid indicates the presence of flavonoids (Evans, 2009). 


\section{Test for anthraquinones}

(i). Borntrager's test: The extract was shaken with $10 \mathrm{ml}$ of benzene, the content was filtered and $5 \mathrm{ml}$ of $10 \%$ ammonia solution was added to the filtrate, the mixture was shaken. Formation of a pink, red or rose colour in the upper part of the aqueous layer indicates the presence of free anthraquinones (Evans, 2009).

(ii). Modified Borntrager's test: the extracts was boiled with $10 \mathrm{ml}$ of aqueous sulphuric acid and filtered hot. The filtrate after cooling to room temperature was shaken with $5 \mathrm{ml}$ benzene, the benzene layer was separated and half of its volume, $10 \%$ ammonium hydroxide was added. A pink, red or violet coloration in the ammonia phase (lower phase) indicates the presence of combined anthraquinones or anthraquinone derivatives (Evans, 2009).

\section{Test for tannins}

(i). Ferric chloride test: $0.5 \mathrm{~g}$ of the extracts was stirred with $10 \mathrm{ml}$ distilled water and filtered. Two drops of $1 \%$ ferric chloride solution was added to $2 \mathrm{ml}$ of the filtrate. Formation of a blue-black (hydrolysable/gallitannins) or green or blue-green (condensed/cathehic tannins) precipitate indicates the presence of tannins (Evans, 2009).

(ii). Lead sub-acetate test: To a small quantity of the extracts, three drops of lead sub-acetate solution was added. The solution was observed for the presence of green precipitate which indicates the presence of tannins (Evans, 2009).

\section{Test for alkaloids}

$0.5 \mathrm{~g}$ of the extracts was stirred with $5 \mathrm{ml}$ of $1 \%$ aqueous hydrochloric acid on a water bath and filtered. Ammonia solution was added to the filtrate until it is basic, then chloroform was added and shake gently to allow separation. The chloroform layer was collected, then dilute $\mathrm{HCl}$ was added and shake gently to separation and the aqueous layer was divided into three.

(i). Dragendorff test: To the first portion, few drops of freshly prepared Dragendorff reagent was added and observed for formation of orange-red to brownish precipitates.

(ii). Mayer's test: To the second, one drop of Mayer's reagent was added and observed for formation of white to yellowish or cream colour precipitates.

(iii).Wagner's test: To the third, $1 \mathrm{ml}$ of Wagner's reagent was added to give a brown or reddish or reddish-brown precipitates, in the presence of alkaloids (Evans, 2009).

\section{Test for steroids/triterpenes.}

(i). Lieberman-Buchard test: a small portion of the extracts was dissolved in chloroform. Equal volume of acetic anhydride was added, followed by concentrated sulphuric acid down the side of the test tube. The mixture was observed for the presence of a brown ring at the interphase which indicates the presence of steroids/triterpenes (Evans, 2009).

(ii). Salkowski test: A small quantity of the extracts was dissolved in $1 \mathrm{ml}$ chloroform and to it $1 \mathrm{ml}$ of concentrated sulphuric acid was added down the side of the test tube. Formation of red coloration at the interphase was taken as an indication for the presence of sterols (Sofowora, 1996).

\section{RESULTS AND DISCUSSION}

The macroscopic examination of Aubrevillea kerstingii revealed grey coloured outer stem bark and yellowish inner bark. The powdered stem bark has smooth texture, mild odour and a slightly bitter taste. The stem bark also showed fibrous fracture and a quill shape when dried. The bark has an average length of $14.82 \pm 0.20 \mathrm{~cm}$ and width of $0.5 \pm 0.10 \mathrm{~cm}$. The results of the macroscopic examination are depicted in Table 1. 
Table 1: Macroscopic examination of Aubrevillea kerstingii Stem bark

\begin{tabular}{ll}
\hline Macroscopic characters & Results \\
\hline Colour of inner bark & Yellow \\
Colour of outer bark & Grey \\
Texture & Smooth \\
Taste & Slightly bitter \\
Odour & Mild odour \\
Fracture & Fibrous \\
Shape & Quill \\
Size & Length $14.82 \pm 0.20 \mathrm{~cm}$, width $0.5 \pm 0.10 \mathrm{~cm}$ \\
\hline
\end{tabular}

\section{Microscopic features of the stem bark}

Microscopic evaluation of plants is an important step in determination of the identity and purity of plant material. The anatomical features are used as criteria for distinguishing various plant species and families. Important microscopic features such as cork cells, cortex, phloem, fibers and calcium oxalate crystals are used as diagnostic features for microscopic evaluation of plants (Srimant et al., 2018).

The microscopic features revealed the presence of a few layers of flattened, thin walled, and radially arranged cork cells found on the outer most part of the bark, well developed cortex, bundles of sclerenchymatous cells and numerous prismatic calcium oxalate crystals. These features are characteristic of plants from the family Fabaceae (Ghani, 1990).

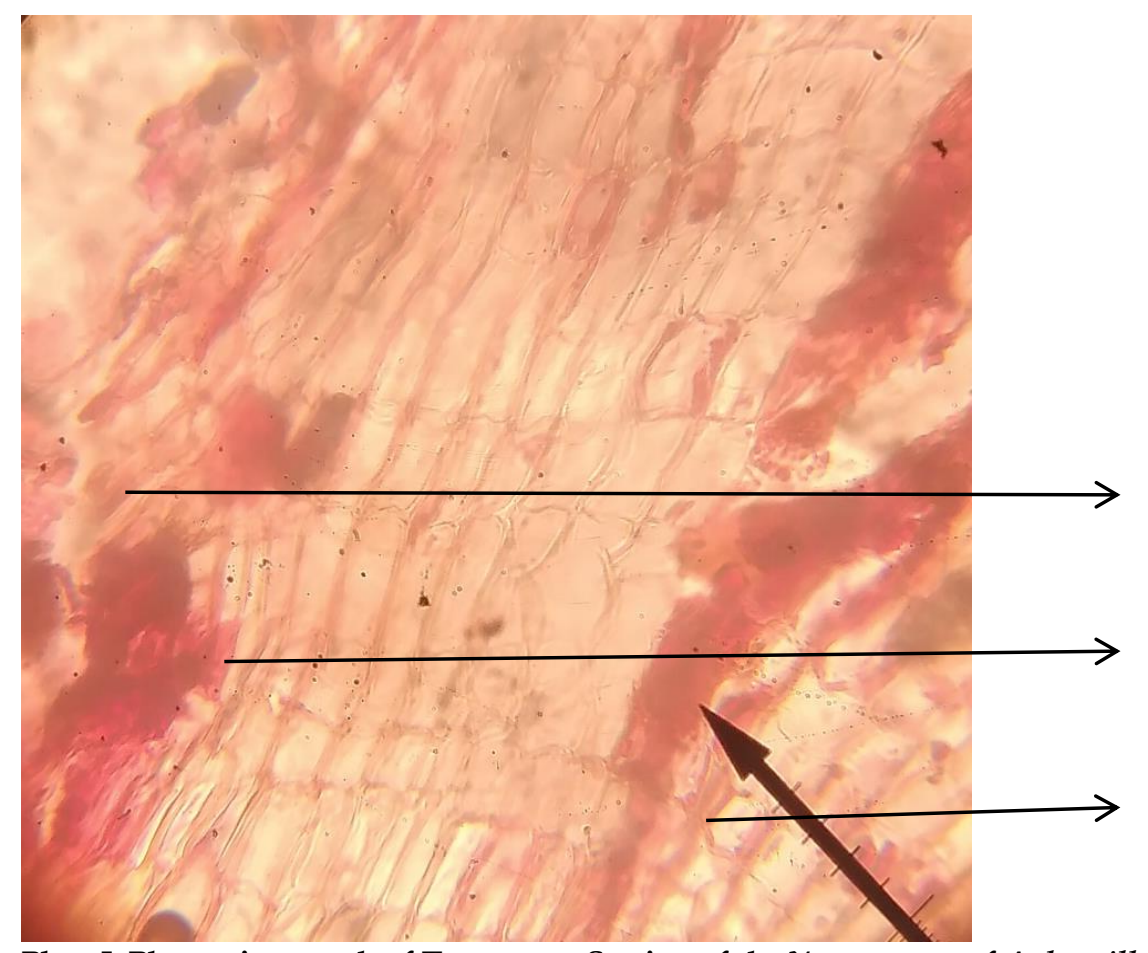

Plate I: Photomicrograph of Transverse Section of the Young stem of Aubrevillea

\section{Cortex}

Cork

Calcium oxalate

Fibre

kerstingii 

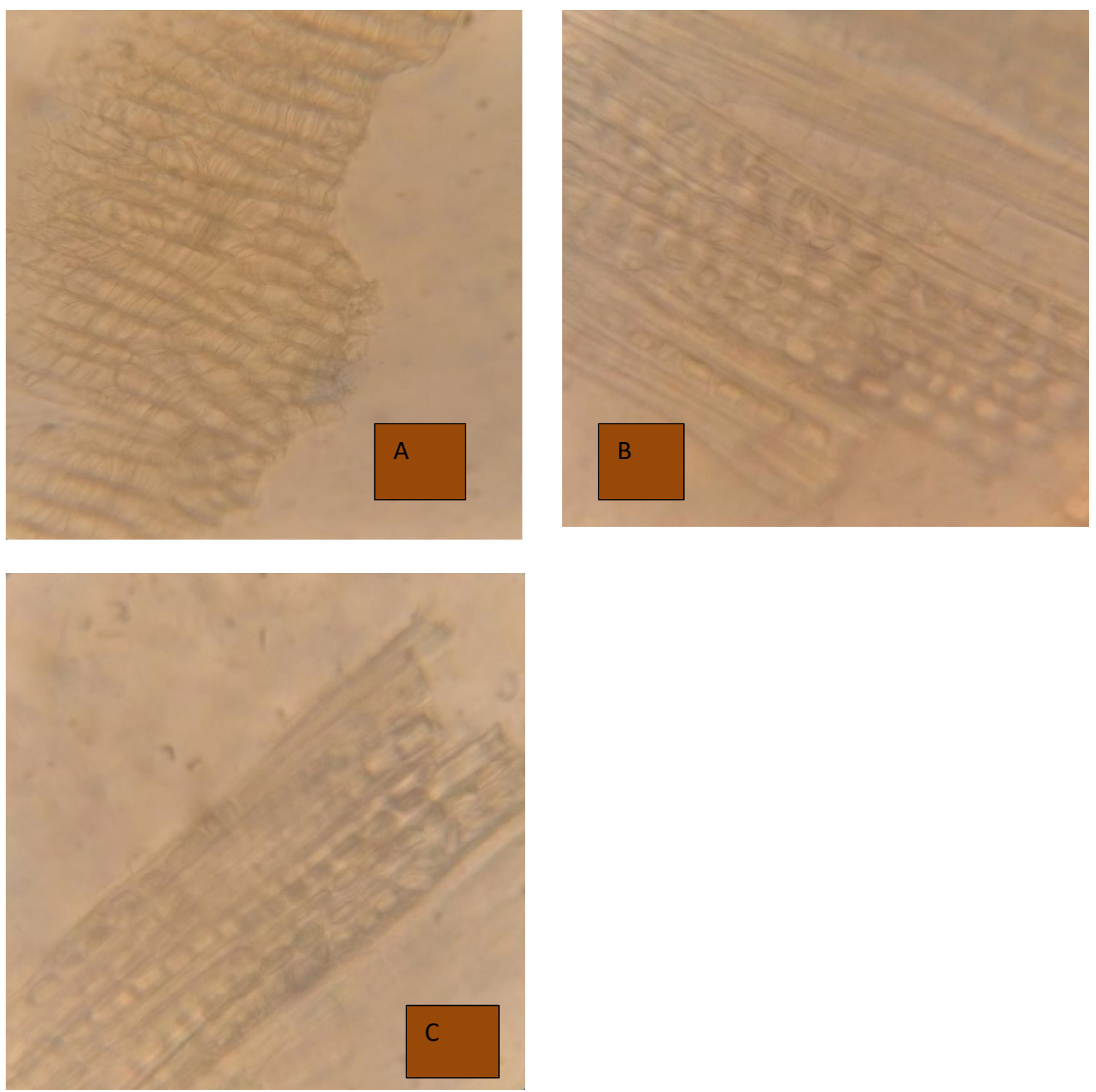

\section{Plate II}

A. Photomicrograph of the powdered stem bark of Aubrevillea kerstingii showing thin walled flattened cork cells (Magnification $\times 400$ )

B. Photomicrograph of the powdered stem bark of Aubrevillea kerstingii showing bundles of sclerenchymatous fibre (Magnification $\times 400$ )

C. Photomicrograph of the powdered stem bark of Aubrevillea kerstingii showing prismatic calcium oxalate crystals (Magnification $\times 400$ )

\section{Chemo-microscopic features of the stem bark}

The chemo-microscopy of the powdered stem bark of Aubrevillea kerstingii revealed the presence of cellulose cell wall, lignin, suberin, tannins, starch and calcium oxalate crystals Table 2. 
Table 2 - Chemo-microscopical Features of Powdered stem bark of Aubrevillea kerstingii

\begin{tabular}{lll}
\hline Constituents & Observation & Inference \\
\hline Cellulose cell wall & Cell wall of the parenchyma cells stained blue & Present \\
Lignified cell wall & Sclerenchymatous fibres stained pink & Present \\
Suberin & The walls of the cork cells stained orange red & Present \\
Calcium carbonate crystals & $\begin{array}{l}\text { Dissolution of crystals was observed without } \\
\text { effervescence } \\
\text { Dissolution of crystals was observed without } \\
\text { effervescence }\end{array}$ & Present \\
Mucilage & No red or pink stain was observed & Absent \\
Starch & Parenchyma cells were stained blue & Present \\
Tannins & The cortical cells stained bluish black & Present \\
Aleurone grains & No yellow stained grains were observed & Absent \\
\hline
\end{tabular}

\section{Physicochemical Constants of the Stem Bark}

Physicochemical parameters such as moisture content, ash values and extractive values are also vital for evaluation of plant materials (Chanda, 2014). Physicochemical parameters determined in this study showed moisture content to be $8.2 \% \pm 0.07$. This value falls within the limits for water content (6 -14\%) for vegetable drugs (Abere and Onwukaeme, 2012). High moisture content promotes the growth of microorganisms leading to degradation and spoilage in storage (Thomas et al., 2008). The total ash value was $9.23 \pm 0.56$, acid insoluble ash $1.49 \pm 0.12$ and water soluble ash $5.52 \pm 0.10$. Ash values are also important in detecting the quality and purity of crude drugs as they determine the level of inorganic composition and other impurities present in the drug (Gupta and Sharman, 2012). The water soluble ash is used to estimate the presence of inorganic compounds in the crude drug. The acid insoluble ash consists of mainly silica and indicates contamination with earthly material. Lower ash value indicates fewer amounts of impurities in the plant material (Rakholiya and Chanda, 2012).

The alcohol extractive value was $26.50 \pm 0.61$ and water extractive value was $33.37 \pm 0.36$ (Table 3). The extractive values are useful in determining or estimating the chemical constituents present and their solubility in particular solvent. It is also useful in determining whether the crude drug is exhausted or not (Tatiya et al. 2012). High extractive value in this study suggests that the plant has high concentration of chemical constituents.

Table 3: Physicochemical Parameters of Powdered Aubrevillea kerstingii stem bark

\begin{tabular}{ll}
\hline Physicochemical parameters & Values $(\% \mathbf{w} / \mathbf{w}) \pm$ SEM \\
\hline Moisture content & $8.2 \pm 0.07$ \\
Total Ash value & $9.23 \pm 0.56$ \\
Acid Insoluble ash & $1.49 \pm 0.12$ \\
Water Soluble ash & $5.52 \pm 0.10$ \\
Ethanol Extractive & $26.50 \pm 0.61$ \\
Water Extractive & $33.37 \pm 0.36$ \\
\hline
\end{tabular}


Preliminary Phytochemical Screening of Aubrevillea kerstingii Stem bark extracts

Preliminary phytochemical screening revealed the presence of triterpenes and tannins in the n-hexane extract. Flavonoids, triterpenes, saponins and cardiac glycosides were detected in the ethyl acetate extract. Saponins, triterpenes, flavonoids, tannins, alkaloids and carbohydrates were present in methanol extract (Table 4).

Table 4: Preliminary Phytochemical Screening of Aubrevillea kerstingii Stem bark extracts

\begin{tabular}{|c|c|c|c|}
\hline Test & n-Hexane & Ethyl acetate & Methanol \\
\hline \multicolumn{4}{|l|}{ Carbohydrate } \\
\hline Molish's & + & - & + \\
\hline Fehling's & + & - & - \\
\hline \multicolumn{4}{|l|}{ Cardiac glycosides } \\
\hline Keller-Killiani's & - & + & + \\
\hline Kedde's & - & - & + \\
\hline \multicolumn{4}{|l|}{ Cyanogenetic glycosides } \\
\hline \multicolumn{4}{|l|}{ Sodium Picrate paper } \\
\hline & - & - & - \\
\hline \multicolumn{4}{|l|}{ Saponins } \\
\hline Frothing & - & - & + \\
\hline Hemolysis & - & - & + \\
\hline \multicolumn{4}{|l|}{ Flavonoids } \\
\hline Shinoda's & - & + & + \\
\hline Sodium hydroxide & - & + & + \\
\hline \multicolumn{4}{|l|}{ Anthraquinones } \\
\hline Borntrager's & - & - & - \\
\hline Modified Borntrager's & - & - & - \\
\hline \multicolumn{4}{|l|}{ Tannins } \\
\hline Ferric chloride & + & + & - \\
\hline Lead sub-acetate & + & + & - \\
\hline \multicolumn{4}{|l|}{ Alkaloids } \\
\hline Dragendorrf's & - & - & + \\
\hline Wagner's & - & - & + \\
\hline Mayer's & - & - & + \\
\hline \multicolumn{4}{|l|}{ Steroids/triterpenes } \\
\hline Liebermann-Buchard's & + & + & + \\
\hline Salkowski's & + & + & + \\
\hline
\end{tabular}

Keys: Present $=+$, Absent $=-$

\section{CONCLUSION}

This study revealed important microscopic, physicochemical parameters and phytochemical constituents that can be useful in identification and authentication of stem bark of Aubrevillea kerstingii. Since there are no previously published pharmacognostic parameters on stem bark 
of Aubrevillea kerstingii, this work can serve as standard which can be incorporated in to the herbal monograph or pharmacopoeia.

\section{REFERENCES}

Abere, T. A., and Onwukaeme, D. N. (2012). Pharmacognostic evaluation of the leaves of Secamone afzelii (Schult) K Schum (Asclepiadaceae). Tropical Journal of Pharmaceutical Research, 11(1), 125-131.https:/ / doi: 10.4314/tjpr.v11i1.16

Burkill, H. M. (1985). The useful plants of tropical West Africa. Richmond, UK, Kew Royal Botanical Garden, London, 1, 252-253.

Chanda Sumitra (2014). Importance of pharmacognostic study of medicinal plants: An overview. Journal of Pharmacognosy and Phytochemistry: 2 (5): 69-73.

Evans, W.C. (2002).Trease and Evans pharmacognosy 15th edition, W.B. Saunders Ltd London, 191-393.

Ghani, A. (1990). Introduction Nigeria, 45, 187-197.to pharmacognosy. Ahmadu Bello University Press, Ltd. Zaria,

Gupta, P. C. and Sharman, N. (2012). Pharmacognostic studies of the leaves and stem of of Careya arborea Roxb. Asian Journal of Tropical Biomedicine. 2(5): 404-408. https://doi.org/10.1016/S2221-1691(12)60065-3

Kalpna Rakholiya and Sumitra Chanda (2012). Pharmacognostic, Physicochemical and Phytochemical Investigation of Mangifera indica L. var. Kesar leaf. Asian Pacific Journal of Tropical Biomedicine S680-S684. https://doi.org/10.1016/S2221$\underline{1691(12) 60295-0}$

Kandati, V., Govardhan, P., Reddy, C. S., Nath, A. R., and Reddy, R. R. (2012). In-vitro and in-vivo anti-inflammatory activity of Andrographis serpyllifolia (Rottl. Ex Vahl.) Wt. International Current Pharmaceutical Journal, 1(8), 199-204. https://doi.org/10.3329/icpj.v1i8.11250

Lemmens R.H.M.J (2006), Aubrevillea paltycarpa Pellegr. In: Loupe, D., Oteng-Amoako, A.A and Brink, M (Editors). PROTA (Plant resources of Tropical Africa/ Ressources vegetales de l"Afrique tropicale) Wageningen, Netherlands. Assessed 14 November, 2019

Raina H, Soni G, Jauhari N, Sharma N, Bharadvaja N (2014). Phytochemical importance of medicinal plants as potential sources of anticancer agents. Turkish Journal of Botany, 38:1027-1035.

Raju, V.H., Ganapaty, S., Prasanna, S.S., Vijaya, G.J., Kishore, P.S., Asif, A.K. (2012). Phytochemical and pharmacological evaluation of Tragia cannabina for antiinflammatory activity, International Current Pharmaceutical Journal 1: 213-216. https://doi.org/10.3329/icpj.v1i8.11253

Rakholiya, K., and Chanda, S. (2012). Pharmacognostic, physicochemical and phytochemical investigation of Mangifera indica L. var. Kesar leaf. Asian Pacific Journal of Tropical Biomedicine, 2(2), S680-S684. https:// doi.org/10.1016/S2221-1691(12)60295-0

Srimant S, Kare MA (2018) Anatomy of Abutilon ranadei Woodr. \& Stafp. A critically endangered species in Western Ghats. Int J Bot Stud 3(1):8-10

Supriatno, and Lelifajri (2018). Effect of sequential extraction on total phenolic content (TPC) and antioxidant activities (AA) of Luffa acutangula Linnaeus dried pulps. In AIP Conference Proceedings (Vol. 2002, No. 1, p. 020062). AIP Publishing. https://doi.org/10.1063/1.5050158

Tatiya A, Surana S, Bhavsar S, Patil D, Patil Y (2012). Pharmacognostic and preliminary phytochemical investigation of Eulophia herbacea Lindl. Tubers (Orchidaceae). Asian Pacific Journal of Tropical Diseases 2(Suppl 1):S50-55 
Thomas, S., Patil, D. A., Patil, A. G., and Chandra, N. (2008). Pharmacognostic evaluation and physicochemical analysis of Averrhoa carambola L. fruit. Journal of Herbal Medicine and Toxicology. 2(2), 51-54.

World Health Organization, (2011). Quality Control Methods for Medicinal Plants. WHO, Geneva, Switzerland, Page 31. 